\title{
3
}

\section{The World with(out) Others, or How to Unlearn the Desire for the Other}

\author{
Kathrin Thiele
}

What are we to do with Gilles Deleuze's most fascinating yet troubling text 'Michel Tournier or the World without Others' which can be found in the appendix of The Logic of Sense (1990) and which devotes itself to the reworking of the Crusoe-myth in Michel Tournier's Friday from 1967? Does this text, as Peter Hallward once argued, ultimately show that 'Deleuze works very literally toward a world without others; that he denies the philosophical reality of all relations - with and between others' (1997, p. 530)? Does Deleuze's utterly non-moralizing philosophy - and that it is non-moralizing is probably both the best known and the most significant feature of his thought - does it, in its striving for a thought of 'difference in itself', lead us into the dead end of an absolute solipsism; into 'the singular as absolute, beyond relation, as sovereign or self-constituent' (Hallward 1997, p. 530)? And, thus, do we have to read Deleuze's article as his most explicit and radical statement of a move 'out of this world' - philosophically challenging but ethico-politically inefficient, a claim Hallward makes in view of Deleuze's œuvre as a whole.

Deleuze writes a philosophy of (virtual) difference without (actual) others. He intuits a purely internal or self-differing difference, a difference that excludes any constitutive mediation between the differed. Such a philosophy precludes a distinctively relational conception of politics as a matter of course. (Hallward 2006, p. 162)

All of these are serious charges, and much more than a mere theoretical disagreement regarding the notion of the singular is at stake here. ${ }^{1}$ Such claims question nothing less than the ethico-political potential of Deleuze's philosophy as such, a charge that becomes especially relevant 
if we examine the importance of this thought for non-phallogocentric and postcolonial perspectives.

So, what to do? In what follows I will argue that while the stated critique is to be taken into account, drawing conclusions too quickly would be both too easy and miss the very singular transformative potential of difference philosophy such as it is exemplified by Deleuze. I do not wish to downplay the challenges that the question of otherness addressed to Deleuze raises - a challenge that seems plausible at first sight, given Deleuze's rejection of all forms of recognition and representation, that is, all mediated forms of relating to others that seem to be 'of this world'. Nevertheless, in this article I will develop a different understanding of Deleuze's thought of becoming, its singular mode of becoming-other, than an all too literal reading of 'The World without Others' might suggest. At the same time, we must, of course, also avoid moving towards the other extreme and retreating to a straightforwardly analogical or metaphorical reading that Deleuze himself so strongly worked against. What will be claimed here is that instead of leading us to the blunt elimination or rejection of questions of otherness or relationality, something very different is at stake in Deleuze, both in his thought of 'difference in itself' in general terms and in his article on Tournier's novel Friday in particular. What we witness in Deleuze is a transformation of the question of otherness and relationality itself; and what I will show is that rather than disregarding the ethico-political issue of otherness as a most urgent and fundamental question for a 'different' philosophy (such as a philosophy of difference worth its name claims), Deleuze's article makes an effort to exemplify the task ahead of us: to rethink relation - rethink it differently instead of reproducing the same, but rethink it in order to relate anew. ${ }^{2}$

Before I will be able to unfold the specificity of Deleuze's thought of becoming as the (dis-)continuous movement of becoming-other that implicates and addresses the question of otherness and the relating to others, it is necessary to engage in a first step with the criticisms issued against Deleuze's thought. It is important to situate the questions of otherness and relationality proper, which (and here I fully agree with Hallward) truly are at the most fundamental level of engaging with the postcolonial condition. After the assessment of the situation, in a next step I will then discuss Deleuze's text 'Michel Tournier or the World without Others'. ${ }^{3}$ What I hope to bring to the fore in my reading is that, unlike the conclusion drawn by his critics, with Deleuze the question of otherness itself - supposedly (politically) so clear - finds a 
different 'line of flight' and twists away from the (structurally violent) dialectics of self versus other (cf. also Derrida 1999; Levinas 2000; Ettinger 2006). In affirming Deleuze's thought of tout-autres, '[n]ot an Other, but something wholly other (un tout-autre) than the Other' (Deleuze 1990, p. 317), one specific aspect in the thought of difference must be emphasized that Deleuze himself did not make explicit enough, but that - as I propose here - is at the heart of all movements of becoming such as we find them throughout his (and Guattari's) philosophy: the practice of becoming is, as we can say with Gayatri Spivak, most centrally a practice of unlearning (Spivak 1990). Thinking with Deleuze (in the best sense of the term, as Isabelle Stengers has shown us), the goal of this article is both to counter-balance persistent misunderstandings of Deleuze's philosophy of becoming, and to develop further the difficult yet most essential issue of relationality and relatedness in contemporary thought. ${ }^{4}$

\section{Difference in Itself: Elimination or Transformation of the Concern for the Other?}

The criticism that Hallward's (1997) text on Deleuze's Tournier-reading in 'Deleuze and the "World without Others"' articulates (and that he continues in his 2006 book-length study on Deleuze entitled Out of this World: Deleuze and the Philoshopy of Creation) goes to the heart of Deleuze's philosophy of difference. In his reworking of the Western ontological tradition of Being into one of becoming, Deleuze himself never tires to stress the ethico-political entanglements implied by such reformulation into a philosophy of radical immanence. ${ }^{5}$ This is his Spinozian and Nietzschean heritage of an ontology that is an Ethics and of his thinking Beyond Good and Evil. Regarding the position of and the relation to the o/Other, ${ }^{6}$ however, the question is whether this thought of 'difference in itself' - a difference neither starting from nor aiming at identity, but a difference that is only ever different/ciation and to be shown differing (cf. Deleuze 1994, p. 56) - is still worthwhile pursuing, which is precisely what Hallward contests in view of both the world's distribution of powers and the production of inequalities in a fully globalized world: '[Deleuze's] work shares with global capitalism a certain faith in limitless expansion along an infinitely extendible "frontier", on the all too familiar American model' (Hallward 1997, p. 537). In such a world, the question is whether the post-identitarian nomadology that Deleuze (and Guattari) suggest does not rather work in favour of the appropriative (capitalist) power structures 
(cf. Miller 1993) than countering them. What is questioned is therefore nothing less than whether a thought that concerns itself with difference in a purely affirmative way - and consequently rids itself of all forms of 'representation', 'recognition', 'identity', and 'Subjectivity' (with a capital S) - does not fall prey to both a continued essentialization of 'passivity' (as for example in the case of the so-called 'feminine') and of 'subalternity' (as for example with post/colonial subjects) and gives up on any effective political strategy; a Politics (also with a capital $\mathrm{P})$ that is able to bring to a halt the more and more rigid stratifications of this world (cf. Hallward 2006). What we encounter here is, therefore (and again), the very fundamental concern with the general direction of Deleuze's thought, which many critics - feminist, anthropologist, and philosophical - have addressed to Deleuze and Guattari's work from early on; ${ }^{7}$ this time, however, concentrating its powers on the urgent question of otherness - the question of how to approach our 'others' and how to relate in this further and further differentiated and globalized world.

From a strictly Deleuzian perspective one could now easily ask: Why bother in the first place? These fundamentally critical readings of Deleuze's work have been successfully countered by voices of a growing Deleuzian canon, especially in regard to the Deleuzian potential for political and ethical thinking that once more seems to be in doubt here. ${ }^{8}$ Yet, it is the very specificity of the question of otherness and the cosmo-political urgency of this question that for me demands once more a more direct engagement.

One way of responding to such criticisms in view of this specific question could be to claim that in a strict Deleuzian sense and 'proper' Deleuzian terms the question of otherness should no longer be of concern, given that in his philosophy of difference one no longer thinks in terms of a pre-given distinction of self/selves and other(s) but, as Hallward rightly states, in 'singular', that is 'intra- rather than inter-individual' terms: in terms of a "becoming-other", undertaken along a "line of flight" which exceeds all specific containment' (Hallward 1997, p. 534). Thus, the argument could proceed, a thought of becoming in the Deleuzian sense is structurally immune against critiques from theorists of recognition who continue to problematize the dialectical (specific) relation of self and other as constitutive of both subjectivity and collectivities. We could say that they not only confuse cause and effect in regard to this division (assuming first a given subject which then encounters difference instead of seeing the subject as an effect of a process of difference), but they also mistake where difference 
exactly starts (not merely between 'given' entities but always already with-in-between them, constituting and different/ciating every-thing in the first place [Deleuze 1994, p. 209]).

While this is surely sufficient in its (Deleuzian) argumentation, there still remains the question of whether such a complete displacement of the question of otherness does not turn away from and maybe even forget (the notion of) the o/Other as such, and if such a move can truly serve as an argument to strengthen the ethico-political dimension of the thought of difference. Is it really convincing to override the concern for 'otherness' by the mere claim of an (un)becoming-subject that always already becomes-other and thus overcomes any opposition between self and other? ${ }^{9}$ And even more so, would the claim of a turn away from otherness even be a valid reading, given Deleuze's engagement with the question of the o/Other that we find in his reading of Michel Tournier's Friday? ${ }^{10}$ In this sense, Hallward, who in many respects misreads the Deleuzian thought of singular becomings, does scholars who work from a difference philosophical perspective a favour. Not only does he provide us with a chance to re-read one of the most fascinating essays on literature by Deleuze, but also to work through the pressing question that arises if we are to relate Deleuze and postcolonial issues: what, actually, does happen to the ethico-political issue of otherness in Deleuze? The debt of this difficult question we cannot not inherit - so we finally have to learn how to inherit it. And yet, the task ahead is that we will have to inherit it under the premises of a subjectivity that is a becoming-other, situated within an ontology of becoming that is no longer secured by the binary and oppositional discourses of subject versus object, of nature versus culture, or of a truthful macro- versus an inefficient micro-politics. ${ }^{11}$

The question to be answered is therefore: how are we to argue for the singular mode of relatedness in the movements of becoming that Deleuze aims to substitute for the relation of self/selves and o/ Other(s), without at the same time ending up in a world completely without others, without perhaps even a concern for them? How 'to think' the Deleuzian turn away from our given situation (a world structured by very particular identities that exclude and live off all kinds of others (human and non-human) and in which becomingimperceptible cannot look like a political strategy worthwhile trying) towards more molecular dimensions, without seemingly taking flight from the here and now? How to produce a true line of flight for this world by giving these 'other' dimensions a most 'real', a most worldly significance? 


\section{Thinking through Fiction: From 'The World without Others' towards An-other World}

What Deleuze finds most fascinating about his friend's literary reworking of the Crusoe-myth is nothing less than that Tournier's novel Friday achieves in literary form what he himself seeks in his philosophical project: a rewriting of an ontology of Being - static, normative and ahistorical - into an ontology characterized by necessary change, that is an ontology of becoming, movement, and transformation. ${ }^{12}$ To a certain extent Tournier's 1967 novel still gives an account of a Robinsonade, the type of self-constitutive journey to which Daniel Defoe's novel gave the name. However, Tournier's Robinsonade is very different from the one that became the modern myth of enlightened subjectivity. In a moment we will engage with this difference in more detail, but what I would like to emphasize at this point is that in Tournier's Friday it is a process of transformation - a Robinson necessarily becoming-other in a situation that is utterly other to him - that substitutes his predecessor's will for restoration at all cost. We will explore in detail where precisely this transformation with Tournier takes us, but we can already say that what Friday shares with Deleuze's philosophical project is a mode of (literary) thinking - thinking in the strong sense - that rather than reproducing the ever-same (identity) affirms (the event of) difference, and that in a most literal sense pushes this experience to such a degree that thereby the world itself becomes unhinged. In that sense the novel is an experiment, and in this experiment we not only witness how Robinson learns to live on his island, but we ourselves witness a transformation of the way we all live in, with, and of this world. ${ }^{13}$

Comparable then to Deleuze's conceptual worlds, Tournier invents and creates fictitious worlds. ${ }^{14}$ And much like Deleuze, Tournier does this by first of all beginning from somewhere else, by starting from a different angle than the one taken for granted, which '[e]verybody knows and no one can deny' (Deleuze 1994, p. 130). His Friday shatters the most fundamental structure of our being in this world, and it does so by 'telling a different story' and 'asking a different question'. Robinson is no longer the exemplary self-centred subject that wills only what he has lost. Rather, he becomes $a$ Robinson who learns to encounter difference in a different manner, and thereby learns to live-with-others.

In Friday, all of this is already announced at the opening when, still safely placed in the novel's preface and warmly seated in the captain's cabin of the Virginia (the vessel which Robinson has chartered), a conventionally 'modern' Robinson listens to captain Van Deyssel - 'this 
bulky Dutch Silenus, lapped in a luxuriating materialism' (Tournier 1997, p. 9) - who reads Robinson's future in tarot cards. At this point, Robinson, the young man who, as we also learn, has left behind 'a young wife and two children, to seek [his] fortune in the New World' (p. 8) encounters his entire 'fate' by means of these cards. However, rather than a teleological development, his is a fate of crooked transformation, with diverse and contradictory states of becoming. Robinson's fate, which, as the Dutch captain wisely says, is not foretold in 'precise terms' (p. 13), is populated by a multiplicity of ambivalences: leading from the cards of the Demiurge ('an acrobat: his work is an illusion and his order illusory') to Mars ('Robinson the king...'), then the Hermit ('the warrior has become conscious of his solitude'), and Venus ('well, here's something to bring the Hermit out of his hole'), makes him encounter the mysteries of Sagittarius ('Chaos'), Saturn ('a hanged man'), but also the Twins ('the bisexual angel [...] attained to a solar sexuality'), and leads him to the Capricorn ('the door, which is the soul's way out - that is to say, death'), but also to Jupiter ('Jove! Robinson, you are saved, but at the very last moment!') (Tournier 1997, pp. 7-14).

In this soothsayer's account of Robinson's adventures, a whole cartography of subject-forces can be found and Tournier imagines from the very start an-other world: not only a world that starts by truth-telling via tarot cards, but also one which later, once Tournier's Robinson has been stranded on the island, does not concentrate all its powers on a restoration of 'what is' (respectively 'what was' in Robinson's specific case) but becomes a transformative process of worlding without any pre-given telos. In Friday, one could argue, we see unravel before us as much a 'possible' world (understood in the Leibnizian sense) as our supposedly 'real' one, but it is one that is marked by a fundamental difference. And it is this difference that leads to a completely different Robinsonade, one in which encountering the other does not necessarily imply imperialist domination of that other, but instead can lead to a process of learning an-other world. Tournier himself says as much when he reflects on what interested him first in writing this novel:

[For Defoe] Crusoe alone was in possession of the only civilization that existed [...]. I was interested [...] in the elimination of every last vestige of civilization in a man subjected to the corrosive effects of inhuman solitude: the very roots of his life and being are laid bare, and he must then create from nothing a new world, groping in the dark, feeling his way toward discovery, clarity, and ecstasy. Friday - still more virginal, more bereft of civilization than Robinson 
even after his bath of solitude - serves the new man as both guide and midwife. Thus my novel was intended as both inventive and forward-looking, whereas Defoe's was purely retrospective, confined to describing the restoration of a lost civilization with the means at hand. (Tournier 1989, pp. 190-191)

Of course, also in Tournier's novel the figure of Robinson is at first desperate to return at any cost to the world he has lost. Realizing his utter solitude 'brought on a mood of heavy melancholy' (p. 21), and with distracted fervour Robinson, like his Defoeian counterpart, tries everything to escape his lot. Thus, he builds Escape, his very personal 'Ark', which, however, as the story quickly shows is built on very 'sandy grounds':

The growing panic which at first he had managed to control overwhelmed him when he found that he was unable to slide rollers under the keel [...]. The hull was immovable, and in his effort to lever it he succeeded only in loosening one of the side members. After three days of desperate, fruitless effort, fatigue and frustrated fury nearly drove him out of his senses. (pp. 38-39)

And equally, after he has to give up his plan of returning to civilization, this Robinson, like Defoe's, cannot stop busying himself with organizing his life in the manner he thinks of as 'natural'. He starts salvaging anything from the shipwrecked Virginia that still might have relevance for a so-called civilized life, from alcohol, the captain's tobacco, halfbroken furniture to, of course, the Bible. Furthermore in Tournier's account, Robinson is also led towards the measurement and cultivation of the land, as well as the subsequent codification of rules that he himself establishes for his new 'civilized' life on the island. Thus Robinson's 'kingdom' is born: 'In performing the sacred act of writing it seemed to him that he had half-retrieved himself from the abyss of animalism into which he had sunk, and returned to the world of the spirit' (p. 46).

And yet, after having achieved all of this, after having 'returned to the world of the spirit', we as readers have not yet made it very far into the novel. We realize that we are in no way at any end of this Robinsonade, as was the case in Defoe who at precisely this moment, when Robinson has again reached control over his life on the island, introduces Friday - the necessary 'subject' to this new kingdom, the one for whom all of this is built and the one who must be initiated into a humanist and 'enlightened' world. In Friday, however, this first stage - the stage of Mars and the Hermit, if you will - is only the beginning of the journey, 
the stage at which Robinson still remembers - far too vividly - his life with others, before his solitude on the island. Unlike his heroic predecessor ${ }^{15}$ who stands as the ultimate triumph of the Enlightenment belief of civilization defending order, rationality, progress at whatever cost, and thereby silencing the imperialisms underlying this civilization, this (postcolonial) Robinson will have to move on. ${ }^{16}$ In this narrative, gaining control over one's life and the land one is living off is only one side, only the beginning of the story. This Robinson cannot help it but he also experiences another force, a force that unmistakably leads him away to other, stranger, experiences, some of which are more productive than others. And with these experiences of unbecoming - Robinson for a while withdraws literally within the earth, and he also begins to see, encounter, and live on-with the island in a mode of (in-)human sexual relation - this Robinson, in however slow a manner, moves towards 'a different island'; one that is perceivable for both himself and the reader from the start but one that cannot be faced before Robinson's whole structure of being is unhinged.

For if on the surface of the island I pursue the work of civilization tillage, stockbreeding, building, administering, lawgiving - which follows the pattern of human society and is therefore in a sense retrospective, I feel that in myself I am the scene of a more radical process of creation, one which is engaged in finding new and original substitutes for the ruins that solitude has left with me, all more or less tentative and so to speak experimental, but bearing less and less resemblance to the human model from which they sprang. [...] Inevitably a time will come when an increasingly dehumanized Robinson will be incapable of being the governor and architect of an increasingly humanized estate. (Tournier 1997, pp. 111-112)

Lurking in the shadows and in the many dark moments of this account of Robinson's life on the island, the process that he undergoes, even after having encountered Friday, is the painful but 'necessary' experience of doubting the foundations of what it is to be human. And instead of producing a reasonable, enlightened kingdom for which he ultimately would be rewarded by being saved from the island (together with Friday), it is the task of this Robinson to find another way out. But, how does this happen? What is it that makes Robinson become-other in the way that Tournier has in stock for him?

It is helpful to incorporate Deleuze's discussion of Tournier's novel at this point because the very question of 'What happens?' or 'What 
has to happen?' is key to 'Michel Tournier and the World without Others'. Tournier, it has been argued, presents the reader with an 'other' Robinsonade, one that starts from somewhere else, as Deleuze confirms, and which marks 'the first important difference with Defoe's Robinson': a different starting point that subsequently structures the whole narrative. For Deleuze, Friday is a narrative which does not merely replicate the world such as the European Enlightenment myth has pictured it, but effectuates a different Robinson, a 'Robinson becoming elemental on his isle, with the isle itself rendered to the elements' (Deleuze 1990, p. 302). The different starting point, or the difference that Deleuze sees at work and that sets his discussion in motion, turns upon the fact that Friday does not repeat the supposedly single motor of the modern (capitalist) world - economy, as Defoe's text famously does. Rather, Tournier's other Robinson experiences another force as his strongest drive in life: sexuality. The difference that the fictitious world of Tournier creates is a libidinal, sexual subject substituted for the purely rationalizing homo economicus of the 18th century. Against the myth of a 'humanized' yet completely de-sexualized Robinson in Defoe, Tournier sets up a highly sexual Robinson who undergoes a process that will also have to be understood as a 'de-humanization' or (in terms of psychoanalysis) a 'perversion'. According to Deleuze,

instead of bringing an asexual Robinson to an origin which reproduces an economic world similar to our own, or to an archetype of our own [...] [Tournier's] Robinson's final goal, is 'dehumanization,' the coming together of the libido and of the free elements, the discovery of a cosmic energy or of a great elemental Health which can surge only on the isle - and only to the extent that the isle has become aerial or solar (1990, p. 303). ${ }^{17}$

The elaboration of both the 'great elemental Health' and the becoming'aerial or solar' of the island - something that from a perspective indebted to radical immanence might at first generate irritation - will need to be postponed for the moment. For now, it is important to stay a little longer with the significance of Tournier's 'philosophical venture' to start from and imagine an-other Robinson, another subjectivity - one that instead of rationalizing knows a more experimental, a more open structure, and that is hinted at by 'sexuality'.18

As was already elaborated in view of the novel itself, this other - more sexual - Robinson is no longer a Subject-Being, who by merit of being alone on an island unknown to humankind can think of nothing but 
rebuilding what he knew, and who therefore 'naturally' ends up subjectifying everything/-one he encounters to this new world-order, which is in turn nothing but the replication of the old order he represents. To the contrary, Robinson becomes someone who slowly-yet necessarilyexperiences a process of fundamental transformation (perversion). Stressing necessity is in this context essential for Deleuze since, as he states, '[t]he perverse world is a world in which the category of the necessary has completely replaced that of the possible' (Deleuze 1990, p. 320). In view of the close links between Deleuze and Tournier mentioned earlier it is not surprising that Tournier also emphasizes this aspect of 'necessity', and in his account of writing this novel states that in rereading Defoe's Robinson Crusoe he was simply struck by the question: 'If you must live on an island in the Pacific, hadn't you better learn from a native well versed in methods adapted to local conditions rather than attempt to impose an English way of life on an alien environment?' (1989, p. 189).

If we take the Crusoe-myth as one of the exemplary philosophical experiments engaging with the issue of 'who we (Westerners) are', then Tournier returns us to this fundamental question, in all its simplicity, which truly unhinges the world such as we know it (and inherit it from Defoe's Robinson). And yet, posed in this way, the question at the same time brings to the fore the idea that it might not be unreasonable after all to see cooperative behaviour as maybe a much more realistic human trait than the seemingly natural picture of a subject so self-occupied and self-involved that it imposes, no matter what, 'an English way of life', upon all that it encounters.

Beginning from a different point, Tournier triggers a philosophical revolution: he questions who we are on the most fundamental level, and it is not exaggerated to call this level ontological, even if we speak of literature here. For it concerns the question if not precisely the image of thought that seems still so natural - a subjectivity threatened by everything/-one other, a subjectivity most concerned with remaining 'the same' - is instead of realistic rather utterly 'idealized'. It is the question if this is not an image of thought that we might call, following feminist critique and postcolonial deconstruction, phallogocentric, and therefore one that we can learn, also with Deleuze and Tournier, to put into perspective: not as natural, but as representing simply one subject-formation in and of this world - the 'phallic', 'modern' or 'colonial' one. ${ }^{19}$

This creative act to begin from somewhere else (and beginning differently must not be confused with setting a new beginning as another origin) has to be acknowledged as an important philosophical 
achievement, an achievement that leads to the central question: 'what is going to happen in the insular world without Others?' (Deleuze 1990, p. 304). What is going to happen, when all others are gone and when, because of the forced absence of all recognizable others, this world will disintegrate - a world that was structured by the figure of the Other (and up to Lacanianism this was the only possibility of what 'world' could imply)? What happens, when, ultimately, the 'logic of the Other' itself has disappeared, the existence of all o/Others who, as Deleuze says, always 'assure[...] the margins and transitions in this world' (1990, p. 305)? This question of both Tournier and Deleuze gnaws at our most fundamental convictions and beliefs, for it is also the question 'what is actually allowed to happen?'

Before turning back to the novel once more, a significant misunderstanding regarding Deleuze's argument on otherness in 'The World without Others' can now already be corrected. Contrary to what Hallward assumes, Deleuze's interest in otherness is not to ultimately 'work towards' a world without others as a world beyond all specific relations. Rather, both Deleuze's and Tournier's engagements exemplify that what is important is to start again the experimental exploration, to begin anew by imagining a situation in which the structure of the Other (the dialectic of self/other and the Lacanian law of the Other) is no longer simply taken for granted. Thus, instead of once more merely reflecting on a situation in which nobody recognizable is left as the other, what is taken up in Friday and Deleuze's discussion of it, is the task to imagine, differently than Defoe, what is or better what becomes thinkable in such a situation if we do not already assume and start from the ever-same narrative - in both literary and philosophical terms. Tournier stated that he was not convinced by the solution that Defoe finds for his Robinson, a subject that structurally always already relies on the presupposition that all relating implies clearly separated subjects and objects, that it is first of all against the other that we act. And Deleuze, in turn, starts his theorization of the other from a world without others in which not so much the comfort of 'my' other is gone, but most of all the comfort of structural assurance of this world itself is gone, in order to imagine - that is to think - differently. They both explore what could happen - and this means also to question what has been allowed to happen so far - when the world as we know it, the world distributed by the structural Other, who in return 'prevents assaults from behind [...] fills the world with a benevolent murmuring [...] makes things incline toward one another and find their natural complement in one another' (Deleuze 1990, pp. 305-306), has ultimately disappeared. Can - that is, is it allowed 
that - something else happens, something different from what we assume to be truthful to subjectivity since Defoe?

\section{Worlding-with-others: Becoming as Unlearning}

It is important to again turn our attention to Tournier's novel and to stress that it does not jump to the mere opposite - to a scenario in which the shipwrecked Robinson and his new environment harmonize in a seemingly natural way with one another - but chooses a different line of flight. Instead of directly counteracting the implicit prejudice of modernity in Defoe's text by confronting it with a merely oppositional alternative, Tournier's novel attempts to 'un-make' or deconstruct the very dialectic itself at work in such a world-view:

Nevertheless, my novel Friday is not really an anthropological novel. The genuine anthropological novel remains to be written. Its true subject - and an exciting and rewarding subject it is - would be the confrontation and fusion of two civilizations personified by two representative narrators, and it would take place as if under laboratory conditions on a desert island. (Tournier 1989, p. 190)

If we analyse Tournier's objective, it is in a paradoxical sense both more modest and much bolder than any counterposition that would concentrate its powers alone on giving voice to 'the other'. Tournier does not focus his attention on the (very real) possibility of a speaking Friday - the subaltern who can speak - and thereby avoids forcing hierarchies to crumble by choosing finally the (politically correct) right side. And yet, Tournier's intention in this novel does at the same time nothing less than to question the whole system that poses the opposition of self and other in the first place. This move, we can say, is on the one hand modest, because it does not overthrow the inherited structure in one blow and 'the white, western man' (Robinson, but also Tournier) is careful not to fall into the trap of repeating the gesture of 'speaking for' and 'representing' subaltern other(s). In Friday the focus is kept on the one speaking subject that this narrative of the constitution of subjectivity - so far - has produced: Robinson. Also in Tournier's novel Friday doesn't speak. However, what the novel dares - and this move is, on the other hand, so much bolder even if not conclusive is to imagine differently how encountering differences might take place as such. By presenting a Robinsonade in which Robinson undergoes a radical transformation (the 'becoming elemental' in Deleuze's sense), 
Friday dares to imagine a different difference-regime: one no longer bound to the pre-given 'law of the Other', but one capable to learn from and world-with-others differently. By following the journey of Robinson step by step and avoiding the presentation of this process as one that moves towards a pre-established telos, the implicitly reigning presupposition that encountering difference means opposing self and other is itself undone. Slowly, yet necessarily, unbecoming himself, Robinson becomes a figure capable of learning with and from the many painful and exhilarating experiences he undergoes in his life on the island - with and without others. And in the end a world is produced that 'represents a fantastic deviation from our world, under the influence of a transformed sexuality, rather than an economic reproduction of our world, under the impact of a continuous effort' (Deleuze 1990, p. 303). In such a world, the following reflections of Robinson, nearing the end of his journey, become central:

As I think of it, there is nothing very astonishing in the almost crazed intensity with which I [now] watch Friday. What is unbelievable is that I should have lived so long in his presence without, so to speak, seeing him at all. How can I account for that blind indifference, when for me he is the whole of humanity assembled in one person, my son and my father, my brother and my neighbor? (Tournier 1997, p. 208)

'[I]nnocently and superficially' (Deleuze 1990, p. 316), like the figure of Friday himself in the narrative, Friday experiments with an-other, a more different/ciated journey of (un)becoming, in which Robinson is not the one who ultimately gains back what he has lost, but who by looking at Friday himself regains a new space for movement, a space for negotiation and learning as a constitutive dimension of his becoming. Thus, rather than being the acknowledged subject to Robinson, Tournier's Friday presents to us a wholly other (tout-autre) form of subjectivity. With Deleuze we can call this subject one that finally has learned to follow the movement of becoming: instead of taking 'an origin as a starting point', Friday knows 'how to get taken up in the motion of a big wave, a column of rising air, to "get into something" instead of being the origin of an effort' (Deleuze 1995, p. 121).

Starting with the wish of 'mastery', in long and painful steps Robinson unlearns his desire for everything other and with the help of Friday - by merely looking at him - he learns the very simple (or should we say singular?) capacity to move with and to be transformed by his encounters 
(human and non-human) on the island. This alone is meant with the becoming-'aerial and solar' of which the quote from Deleuze earlier spoke. Thus also is Robinson's 'elemental Health', such that after the arrival of the Whitebird - his supposed rescue - Robinson cannot help but feel a deep repulsion towards his so-called civilized human others:

What principally repelled him was not so much the coarse brutality, the greed and animosity that emerged so clearly from the discourses of these [...] civilized and perfectly honorable men. It was easy to imagine encountering men of a different stamp, mild-mannered, benevolent, and generous. For Robinson the evil went deeper, and he defined it to himself as the incurable pettiness of the ends to which all men feverishly devoted their lives. Each was in search of something, some special acquisition, wealth or personal satisfaction; but why that thing more than another? (Tournier 1997, p. 224)

After his transformation, the difficulty for Tournier's Robinson is, therefore, not relating-with-others. Rather, he can no longer endure civilization and its mode of oppositional relation to the other: a mode that he regards as one of 'acquisition' that always borders on greed. Here lies the crux of this Robinsonade. Different to a world-without-others in which a supposedly 'sovereign' and completely 'self-sufficient' Robinson becomes 'absolutist' (Hallward 1997, pp. 538ff), the transformation in Tournier's Robinson entails a de-humanizing and de-subjectivizing process in which only the modus of relating, but by no means the relating itself, becomes undone. To the very contrary, worlding-with and living-together-with both Friday and the island become intensified in Friday, so much so that the economically driven logic of reciprocity and exchange, whereby everybody can ultimately keep himself and the other at a distance, where recognition means measuring against what one has achieved and how much oneself and everything else is worth, is shaken up, and a different praxis of relating is envisioned. It is one in which Robinson and Friday for a short while are allowed to become-other together-on-with the island, and in which, to use an expression by Bracha L. Ettinger, we witness the 'co-emerging I and Non-I prior to the I versus other' (2006, p. 64). Instead of a world distributed and structured by subject, predicate and object, a multi-species becoming - as we can also say with Donna Haraway (2008) - dawns onto this new world. ${ }^{20}$

Both the Deleuzian formula of a 'World without Others' and Tournier's becoming-elemental Robinsonade now appear to us in new light. Rather than metaphors for a new 'heroic' achievement that would once again 
separate Robinson from his environment, clearly distinguishing subject from object, nature from culture, and making Friday speak, the world without others and the becoming-elemental are conceptual-fictitious expressions of the difficult processes of unlearning. In doing so they reveal a strong affinity with what Spivak has asked from intellectuals of 'the West' in order to finally leave behind the Enlightenment-rationalist project with its objectifying dialectics of self versus other. In one of her most famous interviews from 1984, 'The Post-Modern Condition: The End of Politics?' collected in The Postcolonial Critic, her point resonates well with this discussion:

I think first of all that the Western theoretical establishment should take a moratorium on producing a global solution [...] - and this is why the critique of Western metaphysics is so important, as a critique of Western metaphysics in the post-structuralists. I think in the language of commercials, one would say: Try it, you might like it. Try to behave as if you are part of the margin, try to unlearn your privilege. This, I think, would be a lesson that one could draw, in a very crude way, from the post-structuralist enterprise. (Spivak 1990, p. 30)

Tournier's Robinson in as much as Deleuze's striving for a tout-autre can be read as in this way 'trying'. What is significant in Tournier and Deleuze is that both put all their efforts into un-working the logic of the same - the striving for a mere restoration of the same old world in Robinson - by pushing difference to such a degree that everything - every-thing and -other - becomes unhinged. Yet, the un-doing or un-working involved in this process, the dimension that truly makes this becoming a movement towards others, cannot become explicit enough if we articulate it only via the Deleuzian formula of 'the World without Others' (although we are now able to read it differently than literally as a world that has no others) or via Tournier's Robinson, who at the end of his solitude would answer the men of the Whitebird, if they were to ask him what he is living for, 'by pointing one hand the shores of Speranza and with the other to the sun' (Tournier 1997, p. 224). In order to make explicit what Deleuze's and Tournier's account does, we need to bring them in contact precisely with Spivak's postcolonial and feminist perspective. With her, we can learn to read Tournier's Friday as well as Deleuze's thought on otherness and primary relatedness as processes of becoming that first of all mean unbecoming oneself by unlearning what 'privilege' in Spivak's sense means, and that is 'not to 
recover a lost consciousness, but to see [...] the itinerary of the silencing' (Spivak 1990, p. 31).

Becoming in Deleuze and Guattari's sense never starts by opposition. Becoming, which is always only a becoming-minoritarian, means nothing less but 'unlearning' one's own habits and, thus, opening up new spaces for both experimentation and negotiation, which then might lead to macropolitical changes. 'Becoming-minoritarian is a political affair and necessitates a labor of power (puissance), an active micropolitics' (Deleuze and Guattari 1987, p. 292). While this might sound like a too slow process for a new 'Politics of Truths' such as Hallward in a Badiouian sense strives for (cf. Badiou 2009), it is Tournier's Robinson who exemplifies that everything less laborious and intense leads not to a new world but only to the restoration of the very same old one. The task ahead of us - to open up new spaces for negotiation and transformation in this world - starts from nowhere else but with and from ourselves, especially here and now in the 'West'. It demands that we unlearn our privilege, which, to say it with Foucault, might be less a process consisting 'in showing the invisible, but in showing the extent to which the invisibility of the visible is invisible' (Foucault 1998, p. 153).

The expression of a 'World without Others' by Deleuze dares to reformulate the question of otherness itself. Instead of presenting a (final) solution to the question how to save the other from the consumptive desire of the Western self, it explores new modes of how to learn differences differently: a different difference that starts with libidinal energies and sexuality (not economy) and thus opens our imagination to a very 'real' deconstruction of the naturalized phallogocentric order we are still living in.

\section{Notes}

1. If we take Hallward's article 'Deleuze and the "World without Others"' together with Absolutely Postcolonial: Writing between the Singular and the Specific, arguing against the singular and delimiting it from the specific as 'the form of mediation' (Hallward 1997, p. 532), is Hallward's claim against Deleuze's philosophy.

2. For the emphasis in Deleuze's philosophy on the question of 'thinking differently' and re-thinking what is given, cf. Colebrook (2000), Grosz (2005b), and Thiele (2008).

3. This seems to happen in nearly all of the existing critical references to this text (and especially in Hallward 1997). However, only when reading this text within the context of the novel, is it possible to also understand Deleuze's radical formula of a 'world without others', beyond the mere rejection of otherness and relationality. 
4. Cf. Isabelle Stengers' (2011) unique exposition of the inventive method of 'thinking with' in her Thinking with Whitehead.

5. As Deleuze and Guattari note, 'immanence can be said to be the burning issue of all philosophy because it takes on all the dangers that philosophy must confront, all the condemnations, persecutions and repudiations that it undergoes. This at least persuades us that the problem of immanence is not abstract or merely theoretical. It is not immediately clear why immanence is so dangerous, but it is' (1994, p. 45).

6. In this text, the question of otherness is mainly addressed on a structural and/or ontological level, due to Deleuze's specific intervention into the discussion in 'Michel Tournier and the World without Others' and given his philosophy of difference as structurally un-working Hegelian dialectics. However, significant in poststructuralist thinking is that the structural and the specific dimensions, that is, the Other (as law) and the other (as concrete other), are no longer categorically separated. This is why Deleuze uses both 'other' and 'Other', depending on which dimension (structural or specific) he emphasizes. In this text I choose 'o/Other' whenever this double connotation of the question of otherness/difference is addressed, and move in general from a concern of 'the Other' ( $l$ 'Autrui) as structure towards a thought of 'other others' or 'wholly others' (tout-autres), a 'different difference' so to speak, which in radical immanence always only comes in the small case as 'an-other'.

7. For an overview of early feminist critical receptions, cf. Grosz 1994, pp. 161-183. For an explicitly postcolonial critique, cf. Spivak 1999, pp. 248-279. From the anthropological point of view, Miller $(1993,2003)$ has harshly criticized Deleuze and Guattari's nomadology, and from the politico-philosophical point of view, cf. Hallward 2006, and most prominently Badiou (2000, 2009) and Žižek (2004).

8. For further analyses of this question cf. Braidotti $(2002,2006)$, Colebrook (2002), Grosz (2004, 2005a), Patton (2000), Smith (1998) and Thiele (2008).

9. For Deleuzian 'becoming' as a movement of unbecoming, cf. Grosz (2005b).

10. 'Michel Tournier and the World without Others' is not Deleuze's only text in which we find a discussion of the o/Other. It is complemented by passages directly devoted to the question in Difference and Repetition (cf. Deleuze 1994, pp. 254-261) and by the general direction of Deleuze's philosophy of difference. For an account of Deleuze's engagement with the question of otherness, cf. also Bryant 2008.

11. The phrasing of otherness as a debt that we must learn to inherit is itself indebted to the most recent work of Donna Haraway, who pays tribute to otherness in bringing into view other others (even non-human or factfictional others). In recent lectures and articles, she argues (with Derrida) for the task to finally start learning to inherit this world structured by so many violent forms of 'othering'. This task does in no way only concern the past. It has to be seen as a thought of non-linear engagement with past, present and future: 'To inherit the past thickly in the present so as to age the future' (Haraway, Lecture at Utrecht University, April 2011).

12. Deleuze and Tournier shared a close friendship in their adolescence, on which Tournier reflects in his autobiography The Wind Spirit (cf. pp. 127ff). In this context it is interesting to speculate in what sense their friendship 
might have inspired in both the interest in (an ontology of) desert islands in general and in Robinson Crusoe in particular. Cf. also Deleuze's early essay on 'Desert Islands' in which he distinguishes 'continental' from 'oceanic' islands, only counting the latter as 'originary, essential islands' (2004, p. 9).

13. That Deleuze's philosophy of immanence affects thought not only in its abstract sense as 'thinking differently', but also effectuates a different ethicopolitical practice in this world, cf. my discussion of Deleuze and political activism in Thiele (2010).

14. Deleuze uses 'fictitious' in a strong sense, different from the 'factual' but in no way as its simple opposite: 'Everything here is fictitious (romanesque), including theory, which merges with a necessary fiction - namely a certain theory of the Other (Deleuze 1990, p. 318). For ground-breaking work on the interrelatedness of fact and fiction in knowledge- and truth-productions, cf. also again Haraway (1989).

15. Tournier calls this heroic Robinson 'the patron saint of the outdoor-do-ityourselfer' (1989, p. 188).

16. 'For I had wanted to dedicate my book to all of France's immigrant workers, to those silent masses of Fridays shipped to Europe from the third world - some three millions Algerians, Moroccans, Tunisians, Senegalese, and Portuguese on whom our society depends and whom we never see or hear, who have no right to vote, no trade union, and no spokesperson [...] Our affluent society relies on these people; it has set its fat white buttocks down on their brown bodies and reduced them to absolute silence' (Tournier 1989, p. 197).

17. Sexuality here is not to be read in a too narrow sense, merely addressing the discourse of sexuality that our modern economies, as Foucault has shown, have produced. I read this emphasis on 'sexuality' that Deleuze sees as the first significant difference between Defoe and Tournier instead in a much broader - cosmological - sense in which the economical desire for and fixation on the other is opened up again and slowly un-worked by a multiplicity of desires, going far beyond specific sexual identities and/or sexual acts.

18. It is interesting to refer here to what must be one of Deleuze's earliest texts: 'Description of Woman: For a Philosophy of the Sexed Other' (Deleuze 2002). Here, he claims 'a-sexualization' within philosophies of the Other as responsible for the so far missing philosophical status of 'Woman'. Given that this article was originally published in 1945, one might be tempted to read Deleuze as a philosopher of sexual difference avant la lettre. The text, however, shows too many problematic arguments to be counted as an up-to-date feminist engagement, but it already refers to a by then still 'unpublished manuscript' of Michel Tournier, from which Deleuze quotes the famous 'the Other is: "the expression of a possible world", which we again find in 'Michel Tournier and the World without Others' (1990).

19. Also in Friday, the transformative power of sexuality/desire passes through the masculine image of sexuality as 'the little death', but ultimately it arrives at what Robinson himself - at the preliminary end of his process of becoming - describes in the following way: 'There is no longer that loss of substance which leaves the animal, post coitum, sad. My sky-love floods me with a vital energy which endows me with strength during an entire day and 
night. If this is to be translated into human language, I must consider myself feminine and the bride of the sky' (Tournier 1997, p. 212).

20. Though not as explicit as in my chapter here, the most recent discussions of Deleuze's 'Michel Tournier and the World without Others' by Eleanor Kaufman (2011) and Levi R. Bryant (2008) seem in agreement with the argument put forward here. While both argue against a moralistic image of thought or an easy ethics in Deleuze, the ethico-political intention driving Deleuze's deconstruction of the 'Other-structure' is in both of their interpretations not at all in doubt.

\section{Works Cited}

Badiou, Alain (2000) Deleuze: The Clamor of Being. Minneapolis: University of Minnesota Press.

- (2009) The Logics of Worlds: Being and Event II. London and New York: Continuum.

Braidotti, Rosi (2002) Metamorphoses: Towards a Materialist Theory of Becoming. Cambridge and Malden: Polity Press.

- (2006) Transpositions: On Nomadic Ethics. Cambridge and Malden: Polity Press.

Bryant, Levi, R. (2008) Difference and Givenness: Deleuze's Transcendental Empiricism and the Ontology of Immanence. Evanston, IL: Northwestern University Press.

Colebrook, Claire (2000) 'Introduction' in Deleuze and Feminist Theory. Ed. Ian Buchanan and Claire Colebrook. Edinburgh: Edinburgh University Press, pp. 1-17.

- (2002) Understanding Deleuze. Crows Nest: Allen \& Unwin.

Deleuze, Gilles (1990) 'Michel Tournier and the World without Others', in The Logic of Sense. Trans. Mark Lester. New York: Columbia University Press, pp. 301-321.

- (1994) Difference and Repetition. Trans. Paul Patton. New York: Columbia University Press.

— (1995) Negotiations. Trans. Martin Joughin. New York: Columbia University Press.

— (2002) 'Description of Woman: For a Philosophy of the Sexed Other'. Angelaki, 7.3: pp. 17-24.

- (2004) Desert Islands and Other Texts 1953-1974. Trans. Michael Taormina. Ed. David Lapoujade. New York: Semiotext(e).

Deleuze, Gilles and Félix Guattari (1987) A Thousand Plateaus: Capitalism and Schizophrenia. Trans. Brian Massumi. Minneapolis: University of Minnesota Press. (1994) What Is Philosophy?. Trans. Hugh Tomlinson and Graham Burchell. New York: Columbia University Press.

Derrida, Jacques (1999) Adieu to Emmanuel Levinas. Trans Pascale-Anne Brault and Michael Nass. Stanford, CA: Stanford University Press.

Ettinger, Bracha, L. (2006) The Matrixial Borderspace. Minneapolis: University of Minnesota Press.

Foucault, Michel (1998) 'The Thought of the Outside' in Essential Works of Foucault 1954-1984, Vol. 2 'Aesthetics, Method, and Epistemology'. New York: The New York Press, pp. 147-169. 
Grosz, Elizabeth (1994) Volatile Bodies: Toward a Corporeal Feminism. Bloomington, IN: Indiana University Press.

— (2004) The Nick of Time: Politics, Evolution, and the Untimely. Durham, NC: Duke University Press.

_ (2005a) Time Travels: Feminism, Nature, Power. Durham, NC: Duke University Press.

(2005b) 'Bergson, Deleuze and the Becoming of Unbecoming', Parallax, 35 : pp. $4-13$.

Hallward, Peter (1997) 'Deleuze and the "World without Others"'. Philosophy Today, 41.4: pp. 530-544.

— (2001) Absolutely Postcolonial: Writing between the Singular and the Specific. Manchester: Manchester University Press.

— (2006) Out of this World: Deleuze and the Philosophy of Creation. London/ New York: Verso.

Haraway, Donna (1989) Primate Visions: Gender, Race, and Nature in the World of Modern Science. London and New York: Routledge.

- (2008) When Species Meet. Minneapolis: University of Minnesota Press.

Kaufman, Eleanor (2011) 'Ethics and the World without Others', in Deleuze and Ethics. Ed. Nathan Jun and Daniel W. Smith. Edinburgh: Edinburgh University Press, pp. 108-122.

Levinas, Emmanuel (2000) Totality and Infinity: An Essay on Exteriority. Pittsburgh: Duquesne University Press.

Miller, Christopher, L. (1993) 'The Postidentitarian Predicament in the Footnotes of A Thousand Plateaus: Nomadology, Anthropology, and Authority', Diacritics, 23.3: pp. 6-35.

— (2003) "We Shouldn't Judge Deleuze and Guattari': A Response to Eugene Holland', Research in African Literatures, 34.3: pp. 129-141.

Patton, Paul (2000) Deleuze and the Political. London and New York: Routledge.

Smith, Daniel, W. (1998) 'The Place of Ethics in Deleuye's Philosophy: Three Questions of Immanence', in Deleuze and Guattari: New Mappings in Politics and Philosophy. Ed. Eleanor Kaufman and Kevin Heller. Minneapolis: University of Minnesota Press, pp. 251-269.

Spivak, Gayatri Chakravorty (1990) The Postcolonial Critic: Interviews, Strategies, Dialogues. Ed. Sarah Harasym. London and New York: Routledge.

_ (1999) A Critique of Postcolonial Reason: Towards a History of the Vanishing Present. Cambridge, MA and London: Harvard University Press.

Stengers, Isabelle (2011) Thinking with Whitehead. Trans. Michael Chase. Cambridge, MA/London: Harvard University Press.

Thiele, Kathrin (2008) The Thought of Becoming: Gilles Deleuze's Poetics of Life. Berlin/Zürich: Diaphanes.

— (2010) "To Believe in this World as it Is': Immanence and the Quest for Political Activism', Deleuze Studies, 4.4 (Supplement): pp. 28-45.

Tournier, Michel (1989) The Wind Spirit: An Autobiography. Trans. Arthur Goldhammer. London and Sydney: W. Collins Sons \& Co.

— (1997) Friday. Trans. Norman Denny. Baltimore, MD: The Johns Hopkins University Press.

Žižek, Slavoj (2004) Organs without Bodies: Deleuze and the Consequences. London and New York: Routledge. 